\title{
Controlling Effects of Surrounding Rock to Coal Seam Gas Occurrence
}

\author{
Laibin Wang ${ }^{1,2}$, Shiwen Zhang ${ }^{1}$, Jinshan Shen ${ }^{1}$, Zhongwen Zhang ${ }^{1}$, Xiaotong Yang ${ }^{1}$ \\ ${ }^{1}$ College of Earth \& Environment, Anhui University of Science \& Technology, Huainan, China \\ ${ }^{2}$ Key Laboratory of Mine Geological Hazard Control, Huainan, China \\ Email: lbwang@aust.edu.cn
}

Received November 13, 2012; revised December 15, 2012; accepted January 10, 2013

\begin{abstract}
Surrounding rock of coal seam was one of the important factors to gas occurrence. The coal seam gas occurrence was studied by the index of roof strata thickness or sand content rate; we found that there were certain shortcomings. In order to reasonably evaluate the influence of coal seam surrounding rock on gas occurrence in Panji mining area, we quantitatively evaluated the effect of coal seam surrounding rock on gas occurrence by influence coefficient of roof strata thickness, and built six mathematical models of the variational gas content in the mining area which is divided into six gas geological units. The results shows that the coal seam gas content is mainly influenced by $20 \mathrm{~m}$ roof strata in each gas geological unit, the gas content presents the tendency of increase, and with the influence coefficient of strata thickness increases, they exist a significant linear relationship.
\end{abstract}

Keywords: Panji Mining Area; Surrounding Rock of Coal Seam; Gas Occurrence; Influence Coefficient of Coal Seam Roof Strata Thickness

\section{Introduction}

Coal seam gas is methane as the main components of gas that coal material produce in the process of coal accumulation and it has long been considered to be harmful gas on threat to coal mine safety production. Research data showed that stored gas volume accounted for only less than $20 \%$ in coal seam of its generation now, more than $80 \%$ of the gas had escaped to surrounding rock of coal seam or rock outside [1], and its occurrence is not balanced in coal seam, there are obvious zoning, banding characteristics $[2,3]$. Surrounding rock of coal seam was one of the important factors to gas preservation conditions, enrichment degree, general think permeability rock roof is helpful for gas emissions, and hermetic rock is helpful for gas preservation. The research, about the action of coal seam gas controlled by surrounding rock, often studied by the index of coal seam roof lithologic characteristics and sand content rate and so on, however, there are some limitations, with roof lithologic analysis surrounding rock's permeability, rock thickness and the combination of rock characteristics were elided; evaluate surrounding rock permeability with sand content rate, without consideration of the effect of rock mass structure [4-6].

Take Huainan Panji mining area 13-1 coal seam as an example, this paper will evaluate the effect of coal seam surrounding rock on gas occurrence by influence coefficient of roof strata thickness to determine reasonable evaluation of roof thickness values range, and build mathematical models between the influence coefficient of roof strata thickness and gas content. Furthermore, the paper will evaluate the influence degree of surrounding rock of coal seam and gas occurrence.

\section{Overview of the Mining Area}

Panji mining area has four production mine, namely Panyi, Paner, Pansan, Panbei, which located in the secondary anticline of Huainan synclinorium structure-southern and northern limbs of Panji anticline. The geological structure of mining area is relatively developed, the fracture structure can be divided into three groups, two groups fracture (EW and NNE) are given priority to strike, NW fracture take second place. Fold structures are mainly about the Panji anticline including Panji anticline, Taowang anticline and Taodaying anticline, ShangtangGencun syncline, Donggangying secondary syncline and Yeji secondary anticline (Figure 1).

The coal-bearing strata in Panji mining area are Taiyuan formation of Late Carboniferous and Shanxi, Xiashihezi and Shangshihezi formation of Permian. The total thickness of the coal-bearing rock strata is about $800 \mathrm{~m}$, of which Permian is the major coal-bearing strata. 


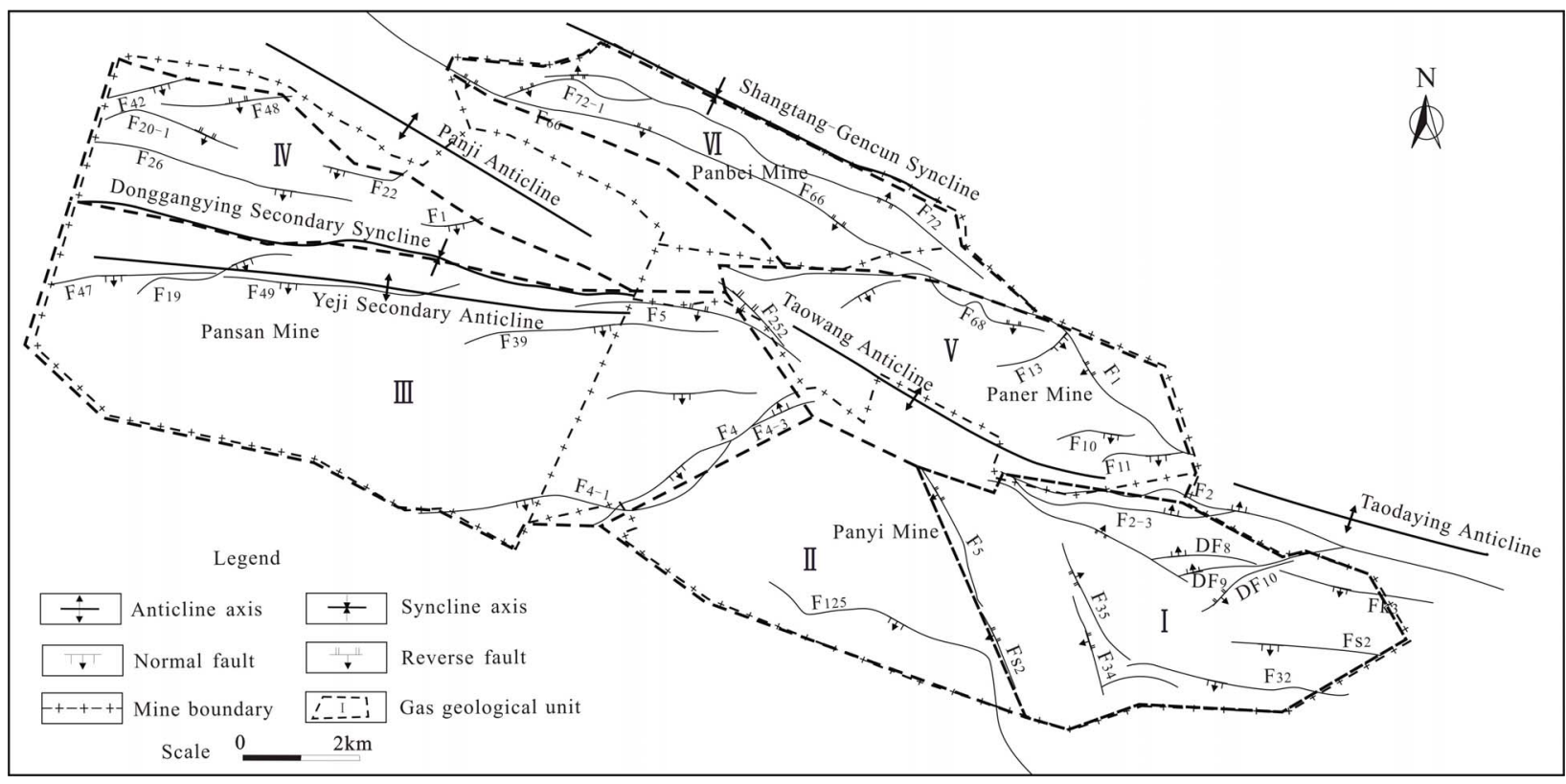

Figure 1. Panji mining area geological structure and gas geological unit division.

According to the structure characteristics of coal bearing rock series cycle, coal seams are divided into A, B, C, D, and $\mathrm{E}$ groups from top to bottom, of which group A, B, and $\mathrm{C}$ are main mining coal groups. 13-1 coal located the group $\mathrm{C}$ of Shangshihezi formation, stable distribution, the average thickness is about $4.2 \mathrm{~m}$, and generally containing 2 - 3 layers coal gangue of carbonaceous mudstone or shale, the structure is relatively simple. Coal seam roof is mainly about mudstone and sandy mudstone, local is fine sandstone.

Coal seam gas content is higher during the process of drilling. Maximum content of production test of coal seam gas is $21.37 \mathrm{~m}^{3} / \mathrm{t}$, and the distribution of gas exists imbalance. Mining area happened 53 times coal and gas outburst, 34 times happened in 13-1 coal seam.

\section{Gas Geological Unit Division}

Coal seam gas is a kind of self-generation and self-accumulation natural gas, and in dynamic migration balance process. In a gas flow field, gas occurrence demonstrated certain regularity, due to the impact of coal seam by geological structure and gas flow field change. Researchers divided gas geological unit mainly from the control of the coal and gas outburst [7-9] and coal seam gas occurrence [10-12] and so on. For more reasonably and accurately analyzing the influence of surrounding rock of coal seam on gas occurrence in Panji mining area, the paper considered two factors of gas migration and preservation and analyzed the influence between surrounding rock of coal seam and gas occurrence in each gas geological unit. The mining area was divided into six gas geological units which respectively were gas geo- logical unit $\mathrm{I}$, from $\mathrm{F}_{5}$ foot wall to $\mathrm{F}_{2}$ hanging wall; gas geological unit II, from $\mathrm{F}_{5}$ hanging wall to $\mathrm{F}_{4}$ hanging wall; gas geological unit III, from $\mathrm{F}_{4}$ foot wall west to Donggangying secondary synclinal axis south; gas geological unit IV, from Panji anticline south to Donggangying secondary synclinal axis north; gas geological unit $V$, from $F_{2}$ foot wall to $F_{1}$ hanging wall; gas geological unit VI: from $F_{1}$ foot wall to Shangtang-gengcun synclinal axis south (Figure 1).

\section{The Control Function of Seam Surrounding Rock to Gas Occurrence}

The influence of surrounding rock of coal seam on gas occurrence is related to the lithology, thickness and distribution of the immediate roof. The rock above immediate roof has certain effect on coal seam gas occurrence, but its effectiveness gradually reduces as the distance increasing. The authors selected 139 reasonable gas content test data in the mining area for the six gas geological unit, made linear regression analyses about the coal seam gas content and the thickness of the surrounding rock and sand content rate. We found their linear relationship was not obvious, for example, for gas geological unit I, the immediate roof strata thickness of coal seam are $3.36 \mathrm{~m}$ at drilling I-8 and III-5, the measured gas content were $18.58 \mathrm{~m}^{3} / \mathrm{t}$ and $8.81 \mathrm{~m}^{3} / \mathrm{t}$, the former immediate roof is the mudstone, the latter is siltstone, its reason is not considered immediate roof strata lithology and above immediate roof strata on gas occurrence; the sand content rate are 0.145 of coal seam roof $10 \mathrm{~m}$ range at drilling $0-\mathrm{I}-7$ and east IV-31, the measured gas content were $13.42 \mathrm{~m}^{3} / \mathrm{t}$ and $6.41 \mathrm{~m}^{3} / \mathrm{t}$, its reason is the sand content rate calculation, 
coarse sandstone, fine sandstone and siltstone were classified as sandstone, mudstone, clay rock and sandy mudstone were categorized as mudstone, but these rocks have different effects on gas occurrence. Other gas geological units in mining area also have such problem, and explain with surrounding rock thickness or sand rate index analysis of the coal seam gas occurrence influences on certain disadvantages.

Based on the above problems, using influence coefficient of coal seam roof strata thickness [4] to evaluate the influence of coal seam surrounding rock on gas occurrence, it not only reflected the surrounding rock lithology changes and proportion, also reflected the structural characteristics of rock mass.

\subsection{Determination of Roof Strata Thickness to Coal Seam Gas Distribution}

Using coal seam as a reference layer, influence coefficient of rock effect thickness actually calculated the influence of roof each rock on gas occurrence. Calculation formula is as follows:

$$
Q=\sum \frac{\mathrm{m}_{i} \times \mathrm{k}_{j}}{\mathrm{~h}_{i}}
$$

where $Q$ is the influence coefficient of coal seam roof strata thickness; $\mathrm{m}_{i}$ is the layer thickness, meter; $\mathrm{k}_{j}$ is the adjustment coefficient layer thickness; $h_{i}$ is the midpoint of the distance of the layer pitch seam, meter.

The roof strata lithologic of 13-1 coal seam are mainly mudstone, sandy mudstone, carbonaceous mudstone and siltstone in mining area. Different lithology of surrounding rock of coal seam have different effect on gas occurrence, so we need to adjust the lithology additional factor of relative gas barrier property [4], respecttively is: mudstone 1.0, carbonaceous mudstone 1.1, coal seam 0.9, sandy mudstone 0.7 , siltstone 0.5 , fine sandstone 0.3 , medium sandstone 0.2 , and gritstone 0.1 .

Statistics roof lithologic of gas content test point selected in the gas geological units in the mining area started from $10 \mathrm{~m}$, calculated once each additional $10 \mathrm{~m}$, and calculated influence coefficient of coal seam roof strata thickness in different thickness rock range from 10 to 70 $\mathrm{m}$, and analyzed the relationship between them and coal seam gas content (Figure 2). As can be seen from Figure 2, for each the gas geological unit in mining area, the relationship between influence coefficient of coal seam roof strata thickness and gas content is maximum $20 \mathrm{~m}$ thickness. This showed that coal seam gas content was mainly affected by coal seam roof $20 \mathrm{~m}$ strata in mining area.

\subsection{The Relationship on Influence Coefficient of Strata Thickness and Gas Content}

Based on the above analyses, we could conclude coal seam gas content was mainly affected by coal seam roof $20 \mathrm{~m}$ rock, and calculated the influence coefficient of coal seam roof strata $20 \mathrm{~m}$ thickness in gas geological unit, (Table 1). We analyzed the relationship between

Table 1. The relationship between influence coefficient of coal seam roof $20 \mathrm{~m}$ and the gas content.

\begin{tabular}{|c|c|c|c|}
\hline $\begin{array}{c}\text { gas } \\
\text { geological } \\
\text { unit } \\
\end{array}$ & location & $\begin{array}{l}\text { influence } \\
\text { coefficient } \\
\text { of strata }\end{array}$ & $\underset{\text { content } /\left(\mathrm{m}^{3} \cdot \mathrm{t}^{-1}\right)}{\operatorname{gas}}$ \\
\hline \multirow{7}{*}{ Unit I } & $0-\mathrm{I}-6$ & 1.7749 & 14.82 \\
\hline & $0-0_{\text {east }}-2$ & 1.7438 & 8.76 \\
\hline & 0-I-7 & 1.9111 & 13.42 \\
\hline & $\mathrm{I}_{\text {east }}-2$ & 2.1477 & 19.28 \\
\hline & $\mathrm{I}_{\text {east }}-3$ & 2.2512 & 21.92 \\
\hline & $\mathrm{I}-8$ & 1.8651 & 18.58 \\
\hline & $\vdots$ & i & ! \\
\hline \multirow{7}{*}{ Unit II } & V-VI5 & 1.4228 & 7.01 \\
\hline & $\mathrm{V}-3$ & 2.0294 & 8.46 \\
\hline & EI-0-11 & 1.2499 & 10.69 \\
\hline & VI-VII7 & 1.6414 & 11.4 \\
\hline & V-VI-19 & 1.9617 & 13.05 \\
\hline & EII-2-7 & 1.5286 & 8.79 \\
\hline & ! & $\vdots$ & $\vdots$ \\
\hline \multirow{7}{*}{ Unit III } & VIII-IX-5 & 1.5308 & 5.58 \\
\hline & WII-3-5 & 1.6174 & 5.98 \\
\hline & VIII-IX-7 & 1.5467 & 9.37 \\
\hline & VIII-IX11 & 1.5652 & 8.94 \\
\hline & WIII-2-7 & 1.0549 & 7.01 \\
\hline & IX15 & 1.6098 & 8.61 \\
\hline & ! & : & ! \\
\hline \multirow{7}{*}{ Unit IV } & XIII-5 & 1.7123 & 6.98 \\
\hline & XIII ${ }_{\text {west }} 9$ & 1.8273 & 9.43 \\
\hline & $\mathrm{XIV}_{\text {east }}-5$ & 2.1801 & 12.78 \\
\hline & XIV-318 & 1.9101 & 7.9 \\
\hline & $\mathrm{XIV}_{\text {west }}-5$ & 1.8943 & 7.45 \\
\hline & $\mathrm{XV}_{\text {east }}-5$ & 2.2658 & 12.78 \\
\hline & $i$ & i & $\vdots$ \\
\hline \multirow{7}{*}{ Unit $\mathrm{V}$} & $\mathrm{III}_{\text {east }}-23$ & 2.1888 & 6.37 \\
\hline & $\mathrm{III}_{\text {east }}-21$ & 1.8024 & 4.85 \\
\hline & Add-07-5 & 1.1084 & 1.48 \\
\hline & III $_{\text {west }}-23$ & 1.5102 & 2.8 \\
\hline & III $_{\text {west }}-22$ & 1.7924 & 4.8 \\
\hline & $\mathrm{IV}_{\text {east }}-24$ & 2.3296 & 5.68 \\
\hline & : & ! & $\vdots$ \\
\hline \multirow{7}{*}{ Unit VI } & VII-34 & 1.5998 & 6.6 \\
\hline & VII-30 & 1.2813 & 2.36 \\
\hline & VII-VIII-18 & 1.3313 & 2.67 \\
\hline & Assist-3-432 & 1.5817 & 4.84 \\
\hline & Assist-3-470 & 1.6271 & 3.88 \\
\hline & IX-8 & 1.832 & 6.74 \\
\hline & : & : & : \\
\hline
\end{tabular}




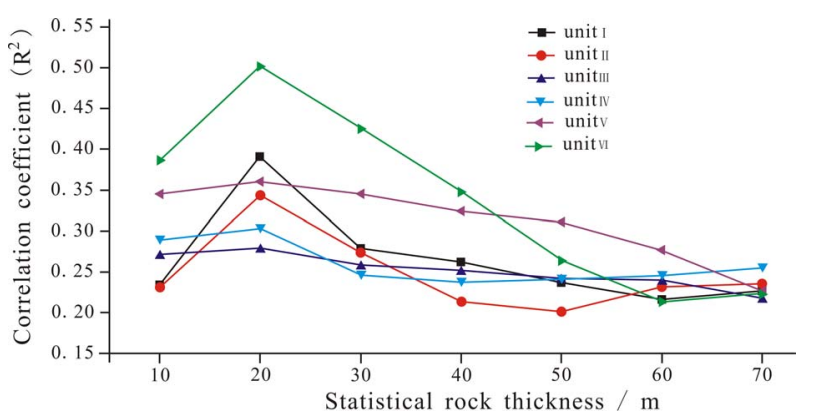

Figure 2. Roof strata thickness and gas content correlation coefficient in each gas unit.

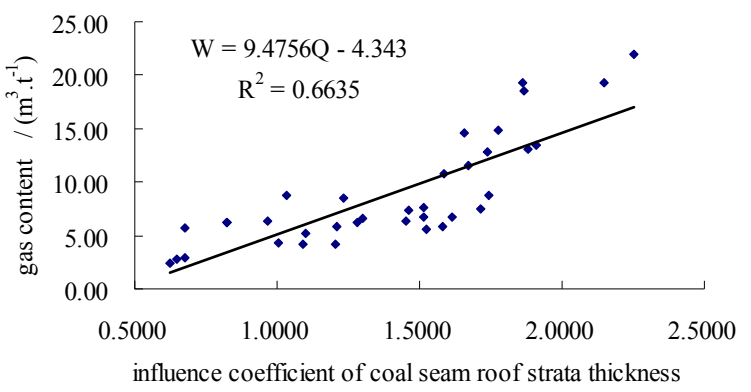

(a)

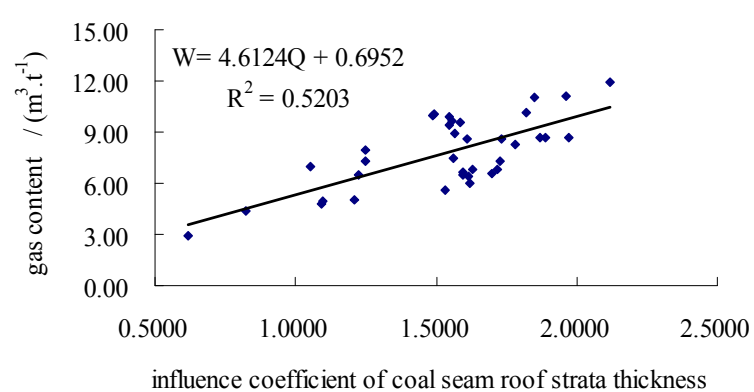

(c)

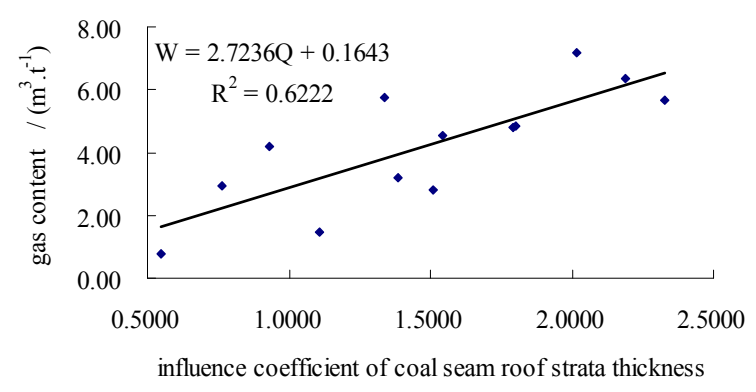

(e)
Table 2. The mathematical model of coal seam gas content distribution.

\begin{tabular}{ccc}
\hline $\begin{array}{c}\text { gas geological } \\
\text { unit }\end{array}$ & $\begin{array}{c}\text { mathematical model of gas } \\
\text { content distribution }\end{array}$ & $\begin{array}{c}\text { correlation } \\
\text { coefficient }\left(\mathrm{R}^{2}\right)\end{array}$ \\
\hline Unit I & $\mathrm{W}=9.4756 \mathrm{Q}-4.343$ & 0.6635 \\
Unit II & $\mathrm{W}=7.477 \mathrm{Q}-2.5342$ & 0.6377 \\
Unit III & $\mathrm{W}=4.6124 \mathrm{Q}+0.6952$ & 0.5203 \\
Unit IV & $\mathrm{W}=8.5371 \mathrm{Q}-6.9063$ & 0.6743 \\
Unit V & $\mathrm{W}=2.7236 \mathrm{Q}+0.1643$ & 0.6222 \\
Unit VI & $\mathrm{W}=7.7439 \mathrm{Q}-7.2394$ & 0.6187 \\
\hline
\end{tabular}

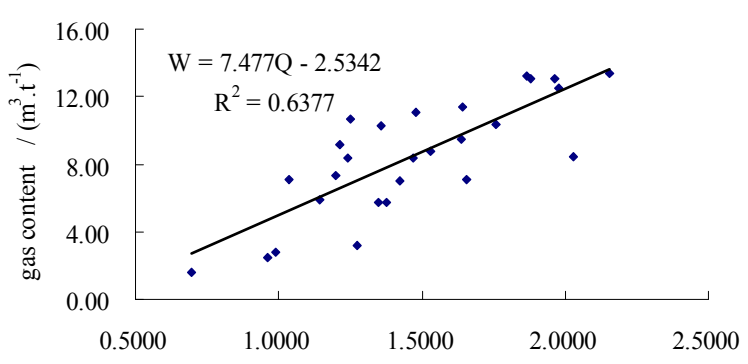

influence coefficient of coal seam roof strata thickness

(b)

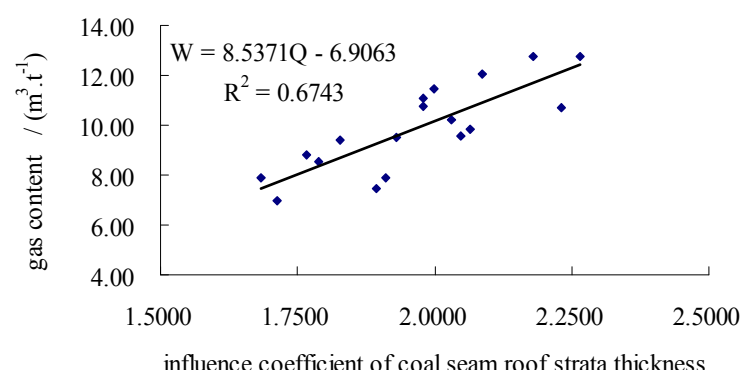

(d)

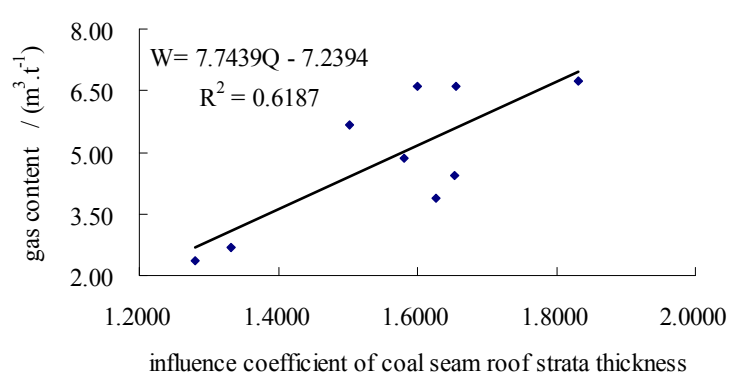

(f)

Figure 3. The relationship between influence coefficient and the gas content in each gas unit; (a) Gas unit I; (b) Gas unit II; (c) Gas unit III; (d) Gas unit IV; (e) Gas unit V; (f) Gas unit VI.

the influence coefficient and the coal seam gas content and built mathematical models between them (Table 2 and Figure 3). We found that coal seam gas content presents the tendency of increase, with the influence coefficient of strata thickness increases, there was positive correlation, and there was a significant linear relationship. It showed that the influence coefficient of coal seam roof strata thickness was larger, rock gas barrier property more better, and more conducive to the preservation of coal seam gas. The influence coefficient of roof strata thickness can be used as an important index to quantitative evaluate the influence of surrounding rock on gas 
content and predict coal seam gas content.

\section{Conclusions}

1) Surrounding rock of coal seam was one the important factor on gas occurrence. The coal seam gas occurrence was studied through the index of roof strata thickness or sand content rate; we found that there were certain shortcomings. The influence coefficient of roof strata thickness, considering the lithology, thickness and their combination characteristics of the coal seam roof strata, was a reasonable evaluation index to coal seam gas occurrence in Panji mining area.

2) The coal seam gas content of Panji mine was mainly influenced by $20 \mathrm{~m}$ roof strata. The influence coefficient of $20 \mathrm{~m}$ roof strata thickness and coal seam gas content had a significant linear relationship, and the gas content presented the tendency of increase, with the increases of the influence coefficient of strata thickness.

\section{REFERENCES}

[1] Y. F. Yao, X. C. Li, Y. Z. Zhou, N. Hao, K. Y. Liu and M. Y. Zhang, "The Effect of Coal Bed Surrounding Rock in Exploration and Development of Coal Bed Gas," Well Testing, Vol. 8, No. 1, 1999, pp. 41-44.

[2] Q. X. Yu, "Mine Gas Prevention and Control," China University of Mining and Technology Press, Xuzhou, 1992, pp. 1-19.

[3] Z. M. Zhang, "Gas Geology," China University of Mining and Technology Press, Xuzhou, 2009, pp. 240-242.

[4] E. Y. Wang and Q. C. Yin, "Application of Deciding the Value of Coal Seam Roof Strata Thickness in Calculating Sand Content Rate," Journal of HeNan Polytechnic Uni- versity (Natural Science), Vol. 27, No. 1, 2008, pp. 4043.

[5] S. C. Yin, Y. L. Zhao and H. Q. Wang, "Analysis on Rock Mass Structure Affecting Coal Seam Gas Occurrence," Zhongzhou Coal, No. 3, 2009, pp. 24-26.

[6] E. Y. Wang, "Lithologic Structure Analysis in Coal-Seam Fault Formation," Journal of China Coal Society, Vol. 30, No. 3, 2005, pp. 319-321.

[7] L. W. Yang, "Application Gas Geological Division in Controlling Coal and Gas Outburst," The Chinese Journal of Geological Hazard and Control, Vol. 8, No. 3, 1997, pp. 21-25.

[8] Y. X. Cao, "Nowledge and Practice for Prediction of Gas Outburst by Gas Geological Unit Methods," Journal of China Coal Society, Vol. 20, Supplementary Issue, 1995, pp. 76-78.

[9] Y. C. Lv, J. H. Hu, M. Zhao and Z. Gao, "Outburst Regional Prediction Based on Delineation of Gas-Geological Unit," Journal of HeNan Polytechnic University (Natural Science), Vol. 29, No. 6, 2010, pp. 715-719.

[10] D. F. Yang, Z. M. Zhang, Y. G. Zhang and G. Xu, "Research the Gas Deposit Law Based on Delineation GasGeological Unit-Take B2 Seam in Xuehu Coalmine as an Example," Journal of Henan Polytechnic University ( $\mathrm{Na}$ tural Science), Vol. 27, No. 4, 2008, pp. 386-390.

[11] Y. F. Lu, P. Chen and X. Y. Tang, "Characteristics of Gas Content of No. 13-1 Coalbed in Panyi Coal Mine of Huainan Field," Coal Geology \& Exploration, Vol. 34, No. 2, 2006, pp. 29-32.

[12] L. B. Wang, Y. G. Shu, J. S. Shen and X. Q. Gao, "Analysis of Regularity and It's Influencing Factors of Gas Occurrence in Seam 13-1 of Pansan Mine," China Coal, Vol. 37, No. 5, 2011, pp. 47-50. 